\title{
NORSK KRONIKK 1986 OG FØRSTE HALVÅR 1987
}

Det mer gjennomgripende arbeid med revisjon av straffelovgivningen går i Norge fortsatt sin gang i Straffelovkommisjonen. Ogsả en gammel og tung lovsak om strafferettslig utilregnelighet og strafferettslige særreaksjoner ligger nå under kommisjonen, riktignok ved et eget underutvalg som ble nedsatt i 1985 .

Når det gjelder større revisjoner, kan det også nevnes at ny straffeprosesslov, som ble vedtatt i 1981, med en rekke endringer i 1985, er satt i kraft fra 1 januar 1986.

Ellers er det mer løsrevne enkeltspørsmål på strafferettens eller -prosessens område som lovgivende organer har arbeidet med i 1986-87.

Heving av den kriminelle lavalder fra 14 til 15 år (som i de andre nordiske land) er en sak som i prinsippet har vært på lovgivningsprogrammet helt siden »Kriminalmeldingen« fra 1978. Det har imidlertid stadig vært vist til at man først måtte ha bygd ut kapasiteten i det sosiale hjelpeapparatet. I januar 1987 mente (Arbeiderparti)regjeringen at denne utbyggningen nå var kommet langt nok, og fremmet lovforslag om å heve lavalderen fra 14 til 15 år. I Stortinget viste det seg imidlertid at de borgerlige partiene mente at tiden ennå ikke var inne; - lovendringen ble riktignok vedtatt i prinsippet, men den skal først settes i verk etter eget lovvedtak. Og dermed er man vel egentlig like langt.

Nye straffebestemmelser mot datakriminalitet ble foreslått av Regjeringen i mars 1987 og vedtatt av Stortinget noen måneder senere. De nye bestemmelsene er i hovedsak i samsvar med tilrådinger fra Straffelovrådet i en utredning fra 1985 (NOU 1985: 31 Datakriminalitet). Som i andre nordiske land er grunnsynet at en i størst mulig utstrekning bør basere seg på allerede gjeldende straffelov når det gjelder å reagere overfor tilfeller av datakriminalitet. Noen typer straffverdige handlinger falt imidlertid utenfor gjeldende straffebestemmelser. Det ble derfor gjort endringer i straffebestemmelsene om bedrageri og om brevbrudd. Videre ble det vedtatt nye straffebestemmelser mot grove tilfeller av ulovlig bruk og en ny bestemmelse i straffelovens kapittel om almenfarlige forbrytelser, rettet mot visse oppregnete handlingar som volder »omfattende forstyrrelse i den offentlige forvaltning eller i samfunnslivet for øvrig«.

Politivold har vært et aktuelt tema i Norge de siste årene. Den sterkeste debatten har dreid seg om hva som faktisk har eller ikke har foregått av politivold, særlig knyttet til forholdene ved Bergen politikammer. Men debatten har fått visse konsekvenser også for regelverket: Regjeringen fremmet høsten 1986 forslag om hjemmel i straffeprosessloven for à opprette scerskilte etterforskningsorganer i saker mot politifolk for rettsstridig atferd i tjenesten. I dag er det politiet selv som etterforsker anmeldelser mot etatens embets- og tjenestemenn. De nye organene, som geografisk skal knyttes til landets ni statsadvokatembeter, skal bestå av en leder som fyller lovens vilkảr for å bli høyesterettsdommer, en advokat med erfaring fra straffesaker og en person med etterforskningsbakgrunn. En hjemmelsbestemmelse som foreslått av Regjeringen ble vedtatt av Stortinget i mai 1987.

Forbrytelser der kvinner er offer har fått større oppmerksomhet de siste årene. Ett mindre utslag av dette er at Regjeringen i en proposisjon som ble satt fram i juni 1987, har foreslått ubetinget offentlig påtale $i$ kvinnemishandlingssaker.

Narkotika er et område der det i mange år har vært stor iver i Norge for nye lovgivningstiltak. Det siste som har skjedd av offisielle tiltak for à endre regelverket, er et høringsnotat fra 
mai 1987 med forslag til nye regler mot såkalt »narkotikaheleri«. Forslaget ligger nær opptil nylig vedtatt lovregler i Danmark, og tar sikte på å ramme dem som får økonomisk fortjeneste av narkotikahandel.

Også reaksjonene overfor promillekjøring er et uuttømmelig emne i norsk strafferettslig debatt. Straffelovrådet fikk i 1984 (under borgerlig samlingsregjering) i oppdrag å utrede dette emnet. Utredningen ble avsluttet i november 1986 og er trykket som NOU 1987: 11 Promillekjøring. - I dag er regelen i Norge er det reageres med ubetinget fengsel straks promillegrensen på 0,5 er overtrådt. Straffelovrådet går i utredningen enstemmig inn for en større nyansering av reaksjonene: bot opp til 1,0 promille og betinget fengsel kombinert med bot opp til 1,5 promille, forutsatt at det er førstegangsovertredelse og det ikke foreligger hensynsløs eller farlig kjøring. Over 1,5 promille mener rådet at ubetinget fengsel fortsatt bør være normalreaksjonen. Men rådet foreslår her at man opphever den særlige bestemmelsen som unntar promillekjøring fra nedsettelsen av minstestraffen for fengsel fra 21 til 14 dager.

Straffelovrådets utredning vil bli sendt på høring. Allerede før den forelå trykket, kom imidlertid en offentlig debatt $\mathrm{i}$ gang, og det er ihvertfall på det rene at området - som tidligere - er høyst kontroversielt i Norge.

Kirsti Coward 